KORNELIJA AJLEC, PhD, Assistant Professor

Department of History, Faculty of Arts, University of Ljubljana

Ljubljana, Republic of Slovenia

kornelija.ajlec@ff.uni-lj.si

UDK 94:339.94(497.1)"1944/1945"(093.2)

327(497.1:73)"1944/1945"(093.2)

originalan naučni rad / original scientific paper

primljeno / received: 29. 12. 2019.

prihvaćeno / accepted: 20. 5. 2020.

https://doi.org/10.29362/ist20veka.2020.2.ajl.129-150

\title{
UNRRA AND ITS ARRIVAL IN YUGOSLAVIA, 1944-1945
}

ABSTRACT: Using resources from the United Nations and in part from the US National Archives, the paper attempts to illustrate the course of negotiations and building of relationships between Yugoslav political representatives, representatives of the Anglo-American Army and the United National Relief and Rehabilitation Administration (UNRRA) during a period of political watershed moments: the consolidation of the Communist Party's authority in Yugoslavia and the victorious siege of Nazi Germany by the Allied Forces followed by their assumption of responsibility for the post-war reconstruction of Europe, including Yugoslavia.

KEYWORDS: Yugoslavia, UNRRA, Allied Military Liaison, Negotiations, Humanitarian Aid

Before the end of World War II, it was already clear that Yugoslavia had suffered terribly under the weight of brutal battles, occupation regimes, and civil wars that devastated its lands. By the autumn of 1944, hunger had spread in the mountainous regions of Bosnia-Herzegovina, Montenegro, and parts of Macedonia. Although Yugoslavia had been receiving humanitarian aid throughout most of the war, ${ }^{1}$ it generally went to units fighting against the Axis. After the Allied recognition of the communist-led National Liberation Movement as the leading resistance force in the country in late 1943, new aid began streaming across the Adriatic, but it remained limited. However, the Partisans began building closer ties with the Allies, mostly the British. Soon, they set up military

\footnotetext{
* The research was made possible by the support of the Fulbright scholarship and the national program of Slovenian History (P6-0235) funded by the Slovenian Research Agency (ARRS). I would like to express my gratitude to the colleagues that made this research possible and to the reviewers and editors for their valuable comments.

${ }^{1}$ On 6 April 1941 the first calls to help Yugoslavia echoed in Washington D.C. In 1942 Yugoslavia thus became part of the land-lease aid program by the United States. Later resistance units were given military aid along with provisions from the British Special Executive Operations (SOE) and the US Office of Strategic Services (OSS).
} 
bases in Bari in Monopoli, while several thousand civilian refugees from the Croatian coastal areas were placed in refugee centers across the Puglia region and later relocated to Egypt. ${ }^{2}$ Due to ideological differences, tension increased between the Partisans and the Allies, but for the most part, the Partisans were given more and more assistance, which they believed they were entitled to. ${ }^{3}$ This was not an unusual sentiment among the smaller nations in the Allied camp, who played a vital role in the struggle against the common enemy. ${ }^{4}$ However, the British, who kept the most contacts with the resistance forces in Central and Eastern Europe, struggled to provide such large amounts of aid. The needs in Europe were great throughout; thus, Yugoslavia was not an exception. In the West for example, the Netherlands had lost one-third of their pre-war gross domestic product. In France and Italy, economy had shrunk by $60 \%$ compared to the 1938/39 fiscal year. In the East, in Ukraine and Belarus, 5 million homes were destroyed, leaving 25 million destitute and without provisions. In general, more than half of the locomotives and rolling stock were out of service in Europe; bridges and viaducts had been bombarded, canals were blocked and of the large European ports only Bordeaux and Antwerp remained operational. ${ }^{5}$ In Yugoslavia, the situation was quite similar. Three quarters of all its bridges had been demolished, all on the Danube and most on the Sava rivers. About half of the rolling carts were destroyed and only 200 trucks remained operational, but most roads were heavily damaged, so they could not travel very far anyway. Only two Adriatic ports remained operational - Split and Dubrovnik. ${ }^{6}$

This data provides only a superficial glimpse at the destruction in Europe and in Yugoslavia, but it already gives a clear indication as to why most of

\footnotetext{
${ }^{2}$ More on Yugoslav Refugees in Egypt, see, for example: Kornelija Ajlec, „Jugoslovanski begunci v Egiptu in njihova politična opredeljenost 1943-1946." Zgodovinski časopis, vol. 67, no. 3-4, (2013), 428-448; Kornelija Ajlec, „Egipatska vlada i rješavanje izbjegličke problematike tijekom Drugoga svjetskog rata", Ćasopis za suvremenu povijest, no. 2, (2014), 295-318.

3 The official stance of the Supreme Command of the National Liberation Army that any assistance given by the allies to Yugoslavia was their obligation not charity. This is apparent from the dispatch from the Supreme Command to the National Liberation Committee for the district of Dalmatia: "All Allied aid /.../ needs to be viewed as a type of a loan that we have been paying off since the first day of the war. It is their moral duty and obligation in front of entire humanity to provide us with at least minimal assistance. Because of this, because of our great contribution to the common Allied interests in the fight against the Nazi-Fascism, we must not accept this aid as mercy, but as something we have earned in all honesty. This, however, does not give us in any way the right to behave arrogantly or humiliatingly towards Allied aid. Our attitudes must be dignified and tolerant, as it is befitting...”. More in: Dušan Plenča, „Jugoslavenski zbjeg u Italiji i Egiptu", u: Istorija radničkog pokreta. Zbornik radova (knjiga 4), ur. Pero Morača (Beograd: Institut za izučavanje radničkog pokreta, 1967), 367-368.

${ }^{4}$ Jessica Reinisch, "Internationalism in Relief. The Birth (and death) of UNRRA", in: Post-War Reconstruction in Europe, Mark Mazower, Jessica Reinish and David Feldman (ed.). (Oxford: Oxford University Press, 2011), 276-277.

5 Jonathan Fenby, Crucible. Thirteen Months that Forged Our World (London: Simon \&Schuster, 2018), 3-7.

${ }^{6}$ D. W. [Duane Wilson, authors note], "Success of a Mission: U.N.R.R.A. in Yugoslavia", The World Today, vol. 2, no. 8, (1946), 377.
} 
Europe looked to the biggest victors of the war - Britain and the United States for assistance. However, Britain especially had its own hardships. The war had cost it a quarter of its wealth and half of its markets. ${ }^{7}$ It was therefore clear that the British alone would not be able to provide all of the aid needed.

A backup plan was in the making since 1941 when Winston Churchill and Franklin D. Roosevelt first discussed international efforts for post-war relief. On 9 November 1943, the plans came to fruition through the emergence of the United Nations Relief and Rehabilitation Administration (UNRRA). ${ }^{8}$ UNRRA was a key organization that helped devastated Europe and China in the first years following the end of the war. The motives for the establishment of UNRRA were initially humanitarian - providing aid without any political, ideological or geostrategic partiality. Therefore, its aim was not only to provide aid to communist countries, but also to the main aggressors, Italy and Germany. So, the inclusion of Yugoslavia in UNRRA's aid program was expected, but the actual delivery depended heavily on the political situation. At the time of the British-led negotiations with Josip Broz-Tito on forming a joint government with Ivan Šubašić and the representative of the royal government-in-exile, UNRRA inevitably became a hostage to the strategic motivations of the participants involved. ' For both the Royal Government and Tito's communist government, securing UNRRA's aid would give them an advantage in the existing power struggle. Similarly, bringing aid into the country would provide the Anglo-Americans with an advantage over the Soviet Union in the geo-strategic positioning of Yugoslavia in the emerging Cold War. ${ }^{10}$ Regardless of the political tug of war, UNRRA became a key element in alleviating starvation and rehabilitating the country's infrastructure. By the end of its Europe operations in 1947, UNRRA's assistance to Yugoslavia in all forms - food, clothing, medical supplies, agricultural supplies, machinery, industrial supplies and equipment, and partly money - amounted to $\$ 415,642,000,{ }^{11}$ or in today's cost around $\$ 4.8$ billion.

\footnotetext{
${ }^{7}$ J. Fenby, op. cit., 3-7.

8 The representatives of 44 founding countries signed the charter treaty at the White House in Washington, D.C. More: George Woodbridge, UNRRA. The History of the United Nations Relief and Rehabilitation Administration, vol. I - III (New York: Columbia University Press, 1950).

${ }^{9}$ In Poland UNRRA was used for political gains as well, but only after it had begun its operations in the country. More on similarities between Poland and Yugoslavia in: Amanda Melanie Bundy, There Was a Man of UNRRA: Internationalism, Humanitarianism, and the Early Cold War in Europe, 1943-1947. (Dissertation. Columbus: Ohio State University, 2017).

${ }^{10}$ More on Yugoslavia in the early Cold War: Lorraine Lees, Keeping Tito Afloat: the United States, Yugoslavia, and the Cold War (University Park: Pennsylvania State University, 1997).

${ }^{11}$ In comparison, Poland was the biggest recipient of aid in Europe, with $\$ 477,927,000$. Italy came second slightly surpassing Yugoslavia with $\$ 418,222,100$ and Greece fourth behind Yugoslavia with $\$ 347,162,000$ (the Dodecanese Islands were a separate entity and received $\$ 3,900,400)$. From the USSR only Belarus and Ukraine were recipients of aid. They received $\$ 60,820,000$ and $\$ 188,199,300$ respectively. The largest recipient of UNRRA aid overall was China with $\$ 617,846,700$. However, UNRRA operations in Asia lasted until 1949 outlasting operations in Europe by two years. However, if we compare these numbers with demographics we get a broader picture of the impact of UNRRA's aid. Greece with approx. 7.3 million inhab-
} 
However, despite UNRRA being an important factor in the post-war reconstruction of Yugoslavia, there are no detailed studies available on the subject. In the 1960s, a renowned historian, Branko Petranović, produced a basic overview based on archival documents of the Bureau of Special Supplies (Zavod za vanredne nabavke - ZZVN). ${ }^{12}$ After that, a number of specialized articles appeared, but they did not deal specifically with UNRRA-Yugoslav diplomatic relations, much less the early stages of these relations that laid the foundations for UNRRA's operations in Yugoslavia. ${ }^{13}$ This paper will therefore attempt to fill a part of that void while mainly referring to documents from the $\mathrm{UN}$ archives, and in part to those in the US National Archives.

\section{The Cairo Agreement, 1944}

The first agreement concerning UNRRA's operations in the country was signed in Cairo on 3 April 1944. The signatories were UNRRA and the Allied Force Headquarters (AFHQ). ${ }^{14}$ This agreement gave the legal foundation to begin preparations for UNRRA's entry into the country, although it was not yet clear when that entry would take place. The first references to the aid delivery to Yugoslavia were recorded on 5 July and 14 July 1944, when Vlas A. Klentsov, the Soviet representative to UNRRA Committee, made a request to Director-General Herbert H. Lehman for immediately delivery of aid to the Yugoslav partisan army, sourced from the Allied military stock in Bari, Italy. He suggested that UNRRA should arrange the delivery of the supplies with the assistance of the Soviet Navy. ${ }^{15}$ Lehman rejected the initiative because UNRRA's operations on the territory of a certain country had to be based on a mutual agreement signed by the party that actually governed the country. In fact, the newly founded national government of the Liberation Movement headed by the Communist Party, a counterpart to the Royal Government-in-Exile, the National Committee for the Liberation of Yugoslavia (NKOJ), considered

itants in 1945 comes in first place with $\$ 48.09$ of aid per capita. Yugoslavia is second with approx. 15 million inhabitants in 1945 and with \$27 of aid per capita, followed by Poland with nearly $\$ 20$ of aid per capita (approx. 24 million inhabitants in 1946). Belarus places fourth with 6.3 million inhabitants and $\$ 9.6$ of aid per capita, followed by Ukraine with $\$ 5.23$ of aid per capita (approx. 36 million inhabitants in 1947), China with $\$ 1.13$ of aid per capita (547 million estimated population in 1950). Italy thus comes in last with a population of 45 million in 1945 and only $\$ 0.92$ of aid per capita. G. Woodbridge, UNRRA, vol. III, 428.

12 Branko Petranović, „Pomoć UNRE Jugoslaviji”, Istorija 20. veka: zbornik radova, vol. 2, (1961), 163-224.

13 Vera Kržišnik-Bukić, „Hrana kao glavni vid UNRRA-ine pomoći Jugoslaviji 1943-1948”, Časopis za suvremenu povijest, vol. 20, no. 3, (1988), 59-76; Kornelija Ajlec, „UNRRA v Jugoslaviji in Sloveniji”, Prispevki za novejšo zgodovino, vol. 53, no. 2, (2013), 79-99; Bojan Himmelreich, „Organizacija preskrbe na osvobojenih ozemljih Slovenije in priprave na povojno obdobje (1944-1945) ", Prispevki za novejšo zgodovino, vol. 49, no. 2, (2009), 109-124.

${ }^{14} \mathrm{G}$. Woodbridge, UNRRA, vol. II, 140.

${ }^{15}$ United Nations Archives and Records Management (UNA), s-1021-0001-0006, Negotiation of UNRRA Agreements, Yugoslavia, 3. 
the original agreement signed on 3 April 1944 as a violation of Yugoslav sovereignty. They demanded a new agreement before any formal UNRRA operations could take place. ${ }^{16}$ As a result, UNRRA had to wait for the formal request of the Yugoslav representatives. Nevertheless, preparations for entry into Yugoslavia continued. First, an UNRRA Yugoslav mission was established in Cairo, but for the time being, it was still subordinate to the superior UNRRA Balkan Mission. Formally, the Yugoslav Mission had already moved to Bari in September, where they mobilized their staff, gathered supplies, and coordinated options for transporting supplies to Yugoslavia with the help of the Allied military mission in Italy. The chief of the Yugoslav Mission became Australian Alan Hall, ${ }^{17}$ who, by December of 1944, had secured 123 personnel and 69 volunteers to work in the upcoming operations. ${ }^{18}$

In order for them to actually get started, the highest echelons had to agree on UNRRA's entry into Yugoslavia. The negotiations took place in a politically uncertain environment of establishing and dissolving the coalition government of the Communists and the Royal Government-in-exile headed by Ivan Šubašić. Such circumstances led to delayed negotiations while the Yugoslav need for aid was very dire. Therefore, the NKOJ began negotiations with the Royal Government-in-Exile and the Allied Army in Italy, where UNRRA's Yugoslav Mission assumed observer status. The purpose of those negotiations was to open the aid delivery channels to Yugoslavia as soon as possible, even if it meant deploying the military. ${ }^{19}$

On the Anglo-American side, the Allied Military Liaison (AML) based in Caserta, Italy, took over the role of intermediary between Yugoslavia and UNRRA. It was a division of the Special Operations Executive (SOE), which was also responsible for providing aid to the occupied countries. ${ }^{20}$ Cooperation between UNRRA and the AML was established by the aforementioned formal agreement on 3 April 1944. ${ }^{21}$ The agreement stipulated, among other things, that the Army would use UNRRA as an agency to distribute aid and supplies for rehabilitation in the Balkans after order and peace had once again been established on that territory. In doing so, both the US and British sides handed over the following responsibilities to UNRRA: ${ }^{22}$

1. distribution of supplies, including food, fuel, clothing, and medicines;

2. care for social services, public health, medical supplies, etc;

${ }^{16}$ UNA, s-1015-0001-15, Report on Activities of UNRRA Balkan mission during August 1944, 14.

${ }^{17}$ United States National Archives (NARA), box 5790, 840.50 UNRRA/1-1245, For Lehman from Keeny UNRRA No. 93, 12 February 1945.

${ }^{18}$ UNA, s-1015-0001-15, Balkan Mission 15th September - 21st December 1944, Progress Report, 2.

19 UNA, s-1015-0001-15, Report on Activities of UNRRA Balkan mission during August 1944, 2.

${ }^{20}$ UNA, s-1015-0001-15, Balkan Mission 15th September - 21st December 1944, Progress Report, 3 .

${ }^{21}$ UNA, s-1015-0011-0018, Letter by A. J. McFarland of Combined Chiefs of Staff in Washington to Herbert H. Lehman of UNRRA, 11 October 1944, 1.

${ }^{22}$ UNA, s-1021-0017-0022, The Balkan Mission, 6. 
3. rehabilitation of utilities and services, agriculture, industry, and transport, which were important for the reconstruction;

4. all other services important for the aid and reconstruction.

The agreement also stipulated that the military would be responsible for the reconstruction in each Balkan country after the liberation for a period of six months. As a result, UNRRA was to be only a subcontractor in this regard and subordinated directly to the military during the so-called military period of reconstruction. ${ }^{23}$ However, UNRRA, through its agreement during the military period, acquired the right to its own headquarters and regional structure, as well as its own hierarchy. The UNRRA's entire organizational structure was subject to the stipulations of the Army, but the latter was obliged to consult with UNRRA on any major operation. The agreement also regulated the share of tasks. During the military period, the Army was responsible for providing the necessities, while the task of UNRRA was to distribute them on behalf of the Army. ${ }^{24}$ The military period was, therefore, a special era, both in the context of the UNRRA operations and as an important process of the post-war reconstruction of each aid recipient.

\section{Negotiations for the Entry of the AML and UNRRA into Yugoslavia}

On September 15, 1944, the Balkan Air Force (BAF) ${ }^{25}$ was tasked by $\mathrm{AFHQ}^{26}$ to organize a series of negotiations with the representatives of the $\mathrm{Yu}$ goslav Royal Government-in-Exile and the Partisans regarding the aid and rehabilitation of Yugoslavia. Initially, negotiations were supposed to take place on the island of Vis in Croatia, but representatives of the US State Department and the British Foreign Office agreed that they should be held on neutral territory in order to include representatives of the Royal Government-in-Exile. Such a position was mainly advocated in order to avoid any misinterpretation about the Allies "playing too much into the hands of the Partisans." ${ }^{27}$ As a result, Bari in

\footnotetext{
${ }^{23}$ Ibidem.

${ }^{24}$ UNA, s-1015-0001-15, Balkan Mission 15 September - 21 December 1944, Progress Report, 4.

${ }^{25}$ Balkan Air Force was headquartered in Bari, Italy, and it operated in the territory of the Balkans, especially of Yugoslavia between June 7, 1944, and July 15, 1945. They included the Royal Air Force (RAF) and the South African Air Force (SAAF). More in, for instance: The Oxford Companion to World War II (Oxford: Oxford University Press, 2005), 79-80; Miloš Kovačević (ed.), Vazduhoplovstvo u narodnooslobodilačkom ratu Jugoslavije (Zemun: Komanda Ratnog vazduhoplovstva, 1965), 86.

${ }^{26}$ Allied Forces Headquarters oversaw all Allied Forces in the Mediterranean from the end of 1942 to May 1945. It was initially founded under General Dwight D. Eisenhower to invade French Northern Africa. Then, the Americans joined the British to coordinate the battles of El Alemein. When Eisenhower took over the Normandy invasion in 1944, AFHQ was helmed by General Henry Maitland Wilson. More: History of AFHQ, Part One, Part Two \& Part Three. Accessible at: https://apps.dtic.mil/dtic/tr/fulltext/u2/a551517.pdf, http://www.dtic.mil/dtic/tr/fulltext/u2/a551521.pdf, http://www.dtic.mil/dtic/tr/fulltext/u2/a550768.pdf (Accessed in December 2019).

${ }^{27}$ UNA, s-1312-0000-0018, Military Negotiations with Representatives of Royal Yugoslav Government and National Committee of Liberation, 8 December 1944, 1.
} 
Italy was chosen for the negotiations, with six representatives of the NKOJ arriving on 25 September and representatives of the Royal Government-in-Exile on 29 September. Due to the delayed arrival of the latter, the AML and UNRRA representatives tried to distract the waiting delegates by arranging banquets and cocktail parties for them. They wanted to create as friendly an environment as possible, steer the negotiations to the desired results, and start supplying Yugoslavia with aid as soon as possible. But even though negotiations had not yet started, the first scandal soon broke out. On 28 September, the following statement was issued on Radio Free Yugoslavia: ${ }^{28}$

... since UNRRA had not accepted the National Committee of Liberation's proposal to distribute aid for Yugoslavia through the organ of the NCL ${ }^{29}$ but planned to set up its own special organization, the NCL was compelled to renounce its aid, though it would have been prepared to receive several control delegates of UNRRA who would look into the proper distribution of aid.

The statement upset the atmosphere in Bari very much, despite the fact that Yugoslav Prime Minister Šubašić wired a rejection of the 3 April Cairo Agreement between the AML and UNRRA, which actually stated that the UNRRA would take care of supply distribution, all of which came to light shortly before the negotiations started. The Allies concluded that it was merely a case of confusion and that the correspondents had referred to the provisions of the first agreement. ${ }^{30}$

Before the negotiations started on 5 October 1944, the representatives of the AML and UNRRA's Yugoslav Mission met and agreed on the starting points for the negotiations. ${ }^{31}$ The coordination led to the following negotiating points: ${ }^{32}$

- the equitable distribution of aid needs to be demanded regardless of nationality, religion and political views;

- the final agreement must ensure the entry of the AML staff and agencies under its auspices into Yugoslavia in order to control distribution;

- the first two items must be guaranteed before negotiations on the technical implementation of the supply even begin;

- the negotiators must not disclose the amount of aid or its origin to the $\mathrm{Yu}$ goslav representatives;

- there should be no impression that the aid would completely solve the shortages in Yugoslavia;

- the issue of subsequent repayment of aid should not be raised for the time being.

\footnotetext{
${ }^{28}$ Ibidem.

${ }^{29}$ National Committee of Liberation.

${ }^{30}$ UNA, s-1312-0000-0018, Military Negotiations with Representatives of Royal Jugoslav Government and National Committee of Liberation, 8 December 1944, 1.

${ }^{31}$ UNA, s-1015-0001-15, Balkan Mission 15 September - 21 December 1944, Progress Report, 7.

32 UNA, s-1312-0000-0018, Military Negotiations with Representatives of Royal Jugoslav Government and National Committee of Liberation, 8 December 1944, 1-2.
} 
At the inaugural meeting, the AML representatives demonstrated to the Yugoslavs the global situation of supply shortages, and the overload of Allied transport, which was primarily still intended to supply the military, while briefing them on Allied assessments of the state of Yugoslav ports. ${ }^{33}$ The Allies dominated the meeting, especially the representatives of the Anglo-American Army, which was an unpleasant surprise to the Yugoslav delegates. According to reports by UNRRA representatives, the Yugoslavs did not know anything about the AML before arriving in Bari. The fact that the UNRRA representatives were mere observers during the negotiations was also received negatively since they were convinced that UNRRA, a supranational international organization, had sold out to the Allied Army. Consequently, they reasoned that the aid could easily turn into a tool for achieving political goals. ${ }^{34}$ The negative impression was exacerbated by the AML representatives who urged Yugoslavia to fulfill the first two starting points requested by the Allies, namely that the distribution of supplies had to be equitable and that Yugoslavia had to provide the AML and UNRRA with all the tools necessary for the successful completion of their tasks, including the entry of Allied staff, who would be tasked to check on the correct progress of distribution. ${ }^{35}$ The word "check on" was translated to the Yugoslav representatives as "control" and since the meaning of the word was consequently lost in translation, the Yugoslavs did not want to agree to the Allied starting points right away. Instead, they asked for a break in the negotiations to consult with their superiors. ${ }^{36}$

The next meeting took place in four days, on 9 October, this time dominated by the Yugoslav delegates. They submitted a comprehensive plan of the country's needs and a supply delivery plan for a three-month military period. In doing so, they did not take into account the starting points stipulated by the Allies at the first meeting. Therefore, the Yugoslav requests and the distribution plan were rejected as being too large-scale. ${ }^{37}$ It quickly became apparent during the negotiations that the views regarding the basic principles of delivery and distribution of aid differed on both sides. While the AML argued that UNRRA should carry out all aid distribution in Yugoslavia, as was the rule in other UNRRA national missions, NKOJ representatives insisted that UNRRA's role should be purely observational and that local authorities would distribute it. ${ }^{38}$ The UNRRA could therefore only monitor and check periodically that local distribution was being carried out in a fair manner, without actually having any other powers. The next two meetings, which took place between 13 and 18 October, did not patch their differences. Nevertheless, the negotiators composed a

\footnotetext{
${ }^{33}$ UNA, s-1015-0011-0018, Summary of Negotiations at Bari, 1.

${ }^{34}$ UNA, s-1021-0024-0018, Yugoslavia, vol. I, Office of Chief of Mission, Historical Monograph, 16.

${ }^{35}$ UNA, s-1015-0011-0018, Summary of Negotiations at Bari, 1.

${ }^{36}$ UNA, s-1312-0000-0018, Military Negotiations with Representatives of Royal Jugoslav Government and National Committee of Liberation, 8 December 1944, 2.

${ }^{37}$ Ibidem.

${ }^{38}$ UNA, s-1015-0001-15, Balkan Mission 15 September - 21 December 1944, Progress Report, 7.
} 
draft agreement that was submitted to the AFHQ and the leadership of the NKOJ, but there was no immediate response. ${ }^{39}$

Instead, the talks moved to the highest level. At a meeting held at the UNRRA Headquarters in Washington, D.C., on 17 October 1944, the directorgeneral of the UNRRA, Herbert H. Lehman, met with Rudolf Bićanić, the director-general of Yugoslavia's foreign trade, who was also Yugoslavia's representative in the UNRRA Committee, and Ivan Frangeš, the Yugoslav chargé d'affaires in the United States. Among Lehman and the Yugoslav representatives, the different points of view were even more pronounced. Bićanić emphasized that the head of the Supreme Military Command in Yugoslavia was Marshal Josip Broz Tito, and that, consequently, no military period could be introduced in Yugoslavia as proposed by the Allied Army. ${ }^{40}$ Lehman tried to reconcile the whole situation by explaining that the UNRRA was not able to operate in Yugoslavia for the time being and that the Army was therefore fully responsible for supply transport and field operations. Lehman stressed, however, that he was ready to negotiate with the Yugoslav Government on the jurisdiction and scope of UNRRA's tasks after the end of the military period, which satisfied Bićanić, even though the issue of the military period was not yet resolved. ${ }^{41}$ Lehman himself considered the current stalemate in the negotiations as senseless, insisting that UNRRA should have at least satisfactory control over the supplies and distribution in order to uphold the principles set out in the UNRRA's core documents. ${ }^{42}$

Despite the rift between the negotiating parties, the talks on the technical implementation of the aid delivery started in Bari while they waited for the resolution of the principle issues. ${ }^{43}$ The Technical Policy Committee was set up in order to insure all the agreements on technical implementation. At the first meeting, negotiating subcommittees were set up to regulate issues regarding the general administrative structure of the AML and UNRRA, procedures of port operations, issues of quantity and type of supplies, transport, public health, etc. $^{44}$ In these more specialized talks, the negotiators managed to break through the political disagreements and distrust. ${ }^{45}$ By 10 November, principle agreements on the operation of almost all the subcommittees had been reached, with the exception of the committee that regulated the entry of the UNRRA personnel into Yugoslavia. ${ }^{46}$ Progress in the negotiations nonetheless allowed for minor progress in the field. Out of 3,500 tons of Yugoslavia's stored supplies, 300

\footnotetext{
${ }^{39}$ UNA, s-1015-0011-0018, Summary of Negotiations at Bari, 1.

${ }^{40}$ UNA, s-1015-0011-0018, Note of meeting between the Director General, Dr. Rudolf Bićanić and Mr. Frangeš, 17 October 1944, 1.

${ }^{41}$ Ibidem.

42 UNA, s-1015-0011-0018, Note of meeting with the Director General and Richard C. Patterson Jr., US Ambassador to Yugoslavia and Major Gates, Military Attache, 24 October 1944.

${ }^{43}$ UNA, s-1015-0001-15, Balkan Mission 15 September - 21 December 1944, Progress Report, 7.

${ }^{44}$ UNA, s-1015-0011-0018, Summary of Negotiations at Bari, 1.

${ }^{45}$ UNA, s-1015-0001-15, Balkan Mission 15 September - 21 December 1944, Progress Report, 7.

${ }^{46}$ UNA, s-1015-0011-0018, Summary of Negotiations at Bari, 2.
} 
tons were shipped to Split by 19 November, with the objective of alleviating the severe food shortages in Dalmatia. There was information that the situation in Split and its surroundings was dire, as there had been no food shipments into the city for the past 14 days. Despite that, there were some issues with the dispatch of the extraordinary transport, as an agreement between the AML and Yugoslavia had not yet been reached. The military mission, however, managed to deliver some supplies under previous military aid agreements, since the said supplies could as well be military, but they were also suitable for alleviating the distress of the civilian population. At the same time, complete teams of UNRRA personnel began to form in Bari, beginning with intensive courses in SerboCroatian language and the Yugoslav cultures.

The main negotiations resumed on 11 November. The issue of the military period was once again the focal point. The AML's draft agreement suggested that the military period should last six months but explained at the meeting that the deadline was longer than would probably be required, as they only wanted to prepare for a longer scenario and appropriate planning of activities. Another controversy was the stipulation that the staff of the AML, and especially the UNRRA, would be unrestricted in Yugoslavia. The Yugoslav side demanded that the number of foreigners entering the country be determined, ${ }^{47}$ which caused another termination of negotiations. Not only did the Yugoslav delegates refuse to accept an unlimited number of foreign representatives on their territory, but they also opposed the possibility that they could move freely around the country or the idea of UNRRA establishing six major distribution points in the country without the express permission of the government. ${ }^{48}$ Article 9 of the draft agreement stipulated: ${ }^{49}$

In order to agree on shipments and be in a position to give authoritative assurances to its respective governments justifying the priorities of calling forward supplies for Yugoslavia, and to keep itself adequately informed concerning the equitable distribution of all supplies, including the use of local resources, M. L. ${ }^{50}$ (Yugoslavia) will be afforded all facilities for its technical advisers to observe the process of distribution throughout Yugoslavia.

These advisers will be AML or UNRRA personnel qualified to give expert opinions or advice on the respective aspects of the problems of distribution that they would observe.

By rejecting the provision, the Yugoslav side was, in fact, violating the AML's basic principle that Yugoslavia should provide the AML and UNRRA with everything necessary for their work and, above all, effective control over the supply. Because Yugoslavia demanded such harsh conditions, the UNRRA observers started to believe NKOJ would rather prevent the delivery of the UNRRA's supplies than accept the AML's stipulations. ${ }^{51}$ Soon, however,

\footnotetext{
${ }^{47}$ Ibidem.

${ }^{48}$ Ibidem, 3.

${ }^{49}$ UNA, s-1015-0011-0018, Draft of Agreement, 1.

${ }^{50}$ Military Liaison.

${ }^{51}$ UNA, s-1015-0011-0018, Summary of Negotiations at Bari, 3.
} 
UNRRA suggested to the AML for the agreement to be slightly amended, indulging the Yugoslav positions. ${ }^{52}$ That was the time when AFHQ commander General Henry Maitland Wilson met with the president of NKOJ, Josip Broz Tito, to offer the following propositions in order to move forward: ${ }^{53}$

- the Yugoslav representatives will take over control of supplies delivered by the AML and UNRRA as soon as they are unloaded from ships in Yugoslav ports;

- the distribution of supplies will take place through channels established by the Yugoslav Government, but adhering to the principle of equality;

- AFHQ will deploy two observers in each port and distribution center. At the same time, the total number of observers in the country would not exceed 25 , but they would have complete freedom of movement for the purpose of monitoring all operations;

- observers would come from the Army or UNRRA, but would not actively participate in the distribution of aid;

- the AML military commander would have the entire UNRRA personnel at his disposal and under his direct command.

Gen. Wilson was ready to sign such an agreement before the end of October of 1944, if the Yugoslav side agreed. ${ }^{54}$ But the fact that those 25 observers would not be the only personnel to arrive in Yugoslavia during the military period was an impediment. Both the AML and UNRRA also needed administrative, technical and medical staff to carry out all of their tasks, and the stipulations did not specify those numbers. That was one of the reasons the negotiations had not been completed by the end of the month but stretched through November and December. Throughout this time, the Yugoslavs did not fully clarify their position, since the consolidation of power was taking place within Yugoslavia, in March of 1945 moving the scale to the NKOJ side with the formation of a national government of the Democratic Federative Yugoslavia under the leadership of Josip Broz Tito. But when the AML's chief negotiators, Major General Ivor Hughes and Brigadier General Percy L. Sadler, announced, after coordinating with their superiors, that the number of AML and UNRRA personnel would be limited to a maximum of 300, the conclusion of the negotiations was at last in sight. The Yugoslavs were finally pleased with the number, and on 19 January 1945, after three tense months, an agreement was signed in Belgrade between the AML's chief negotiators Gen. Hughs and Gen. Sadler, and the president of the new Yugoslav Government, Marshal Tito. ${ }^{55}$ The agree-

\footnotetext{
${ }^{52}$ UNA, s-1015-0011-0018, Note on the proposed cable authorizing signature of proposed agreement between the military and Yugoslav authorities relating to civilian relief during the military period in Yugoslavia, 26 October 1944.

${ }^{53}$ UNA, s-1015-0011-0018, Memorandum of conversation with Major Ernest Gross, 21 October 1944.

${ }^{54}$ Ibidem.

${ }^{55}$ UNA, s-1015-0011-0022, UNRRA Jugoslav Mission: Report for period 8 January - 10 February 1945,12 February $1945,1$.
} 
ment was not signed by the Yugoslav Royal Government-in-Exile, but its representative Sreten V. Vukosavljević stated with his signature that the Royal Government-in-Exile approved the agreement. ${ }^{56}$

\section{The Entry of the AML and UNRRA into Yugoslavia}

In December of 1944, the UNRRA Yugoslav Mission in Bari received an intelligence report outlining Yugoslavia's aid needs. It was estimated that for a successful rehabilitation, transport routes had to be established first in order to deliver supplies from the ports to the people in need. To prevent an outbreak of infectious diseases, the intelligence report stated that large quantities of medical supplies were needed in Yugoslavia. These were arranged by necessity in the following order: sulfonamides, ${ }^{57}$ narcotics, cardiotonics, bandages, antimalarials, vaccines, and serums, STD medications, and antiseptics. ${ }^{58}$ After the drugs came clothing and footwear. Yugoslavia imported most of its textiles before the war, but during the war, the inflow had stopped completely. UNRRA estimated that domestic production was about 16,500 tons of textile products per year at the time, which was about seven times less than the consumption before the war. The lack of textiles could also be linked to a potential outbreak of infectious diseases since it would encourage the spread of typhoid and other epidemics. ${ }^{59}$

UNRRA thus estimated that all said necessities were more urgent than food. The conclusion was based on information that the occupying forces had not been able to transport crops due to a lack of transport connections, especially from Vojvodina and Slavonia. In addition, the partisans began a reorganization of agriculture in 1944 through their local committees in the liberated areas. That also meant a transfer of crop surpluses to areas where food was scarce. That does not, however, imply that there was no shortage. The mountainous regions of BosniaHerzegovina, Montenegro, Lika, Gorski Kotar, and the Dalmatian coast were especially affected. The transportation routes being destroyed was the very reason that surplus food could not reach those areas. For that reason, aid was still necessary, as the following example illustrates. ${ }^{60}$ Just before the agreement between the AML and Yugoslavia was signed at the end of 1944, another exceptional 500-ton shipment was sent to Split, following mass reports of famine in the vicinity of Split, the Cetinje region, and in parts of Bosnia-Herzegovina, where the battles with the Germans had been the worst. It was even reported that at least 600 people had died by the end of November. Despite that, the Yugoslavs did not allow

\footnotetext{
${ }^{56}$ NARA, RG 59, box 5790, 840.50 UNRRA/1-2845, Agreement between the Jugoslav Authorities and The Supreme Allied Commander Mediterranean Theater of Operations, 19 January 1945.

${ }^{57}$ Antibiotics used to treat urinary tract diseases and some general infections.

${ }^{58}$ NARA, RG 59, box 5790, 840.50 UNRRA/1-2845, Agreement between the Yugoslav Authorities and The Supreme Allied Commander Mediterranean Theater of Operations, 19 January $1945,2$.

${ }^{59}$ UNA, s-1312-0000-0018, UNRRA Balkan Mission - Intelligence Division, Intelligence Report No. 2, 8 December 1944, 1.

${ }^{60}$ Ibidem, 2.
} 
the immediate dispatch of aid. During that time, urgent telegrams from the local National Committees of Liberation were sent to the highest levels of the Allied authorities in Bari and London. UNRRA was the main target of criticism for failing to send the necessary aid. It was only under these pressures that the authorities in Yugoslavia allowed the aid delivery. ${ }^{61}$

With this shipment the first AML staff arrived in Split. Their objective was to collaborate with the Yugoslav commission in charge of liaison with the AML, which was supposed to coordinate the reception and distribution of supplies as well. The AML staff reported to Bari the satisfactory distribution of this, the second special shipment, by local Partisan committees to places along the Dalmatian coast. Based on those reports, UNRRA prepared a new 1000-ton shipment of supplies, which arrived in Split only after the agreement was signed at the end of January of 1945. Immediately after the signing, the AML and UNRRA teams in Italy launched a ready system of supply delivery. The first regular shipments under the program were expected to arrive in Split ${ }^{62}$ and Dubrovnik $^{63}$ in mid-February. It was estimated that 10,000 tons would arrive that month, followed by another 36,000 tons in March. ${ }^{64}$

Meanwhile, the organizational structure of the AML and UNRRA in Yugoslavia was being established. A Specialist Group was formed and it consisted of field officers tasked with overseeing the distribution of supplies. The group's leadership fell under the joint command of AML Commander Brigadier F.C. Forestier-Walker and Alan Hall, head of the UNRRA Yugoslav Mission. The implementation of all the stipulations was exclusively in the AML's domain. Two UNRRA and two AML representatives were appointed to the Specialist Group Headquarters, which reported directly to the AML Commander and the Head of the Yugoslav Mission. UNRRA was represented by Lawrence Coolidge Vass and Robert Love. The lower, second level of the hierarchy, orders, instructions, and reports freely flowed between UNRRA and its field officers. They were overseen by the Yugoslav Mission Deputy Head William T. Harris, who was in charge of the Bureau of Distribution and Transport.

During the military period operations, UNRRA had the right to establish independent relations with the Yugoslav authorities in two areas: ${ }^{65}$

1. It independently formed relations with Yugoslav representatives regarding UNRRA-exclusive field operations, as well as with preparations for the post-military period.

2. UNRRA was allowed to establish a separate representative office in Yugoslavia in order to independently plan the post-military period of supply de-

${ }^{61}$ UNA, s-1312-0000-0018, Military Negotiations with Representatives of Royal Jugoslav Government and National Committee of Liberation, 8 December 1944, 8-10.

${ }^{62}$ The Port of Split became operative on 27 October 1944.

${ }^{63}$ The Port of Dubrovnik became operative on 19 October 1944.

${ }^{64}$ UNA, s-1015-0011-0022, UNRRA Jugoslav Mission: Report for period 8 January - 10 February 1945,12 February 1945,1 .

${ }^{65}$ UNA, s-1015-0011-0022, UNRRA Yugoslav Mission: Report for period 8 January - 10 February 1945,12 February $1945,2$. 
livery with the Yugoslav representatives. Its only duty was to regularly inform the AML on developments.

First the UNRRA staff arrived in Yugoslavia on 2 February $1945,{ }^{66}$ followed by others on 9 February. ${ }^{67}$ It is important to note that the number of UNRRA personnel in Yugoslavia during the military period never exceeded 50. ${ }^{68}$ While crossing the Adriatic Sea, Chief Alan Hall wrote them a letter: ${ }^{69}$

I am sure that you will never lose sight of the fact that you are an ambassador of goodwill for the UNRRA. Much of the UNRRA's future depends on the success which this Mission and the individual members of this Mission make of the job which lies before us. /.../If the UNRRA succeeds it will certainly play a great part in the future peace of the world. If it fails, our children may have to do this all over again twenty or thirty years from now.

These words reveal that the UNRRA staff were to follow strict rules in order to give the best possible impression and, above all, not to deteriorate relations with the Yugoslav authorities. Staff members were given a list of 12 "don'ts," as they were dubbed by the Chief of the Mission. They were told that officials could not discuss politics or religion with the local population, nor should write anything that would criticize the Yugoslav political situation. They were not allowed to drink excessively in public, particularly large amounts of local brandy; take photographs; criticize other UNRRA or AML employees in front of the locals; resell UNRRA goods, and they were not allowed to receive gifts or messages from the local population. At the same time, they were encouraged to make the most of their local language skills and to remember they were repaying Yugoslavia for its contribution to the Allied victory. ${ }^{70}$

It was a precise encouragement to the staff before leaving for Yugoslavia, where their first objective was to liaise with the Yugoslav authorities, which were still part of the organizational structure of the Yugoslav National Liberation Movement. As early as December, intelligence reports estimated that the Partisan organizational structure had been developed. The report stated that the National Liberation Authorities in each part of Yugoslavia had set up departments of econ-

\footnotetext{
${ }^{66}$ Most notable representatives were: Barry K. White, Split warehouse officer; Major Stanton Garfield, medical unit officer in Dubrovnik; Nicholas H. Rezak, Senior Regional Officer; Colonel James Viner Delahaye Gordon, Senior Regional Officer; Duane Wilson, Senior Regional Officer; Milton J. Bluestein, Bureau of Distribution and Transport Field Observer; Samuel Mamula, Bureau of Distribution and Transport Field Observer; Perry J. Gangloff, Field Staff; David N. Leff, Field Staff; Sam Rosenberg, Field Staff; Irving Ross, Field Staff; Irving Fasteau, Welfare Division Field Observer; John Hall, Welfare Division Field Observer; Peter Bercich, Trucking Officer. UNA, s-1015-0011-0022, UNRRA Jugoslav Mission: Report for period 8 January - 10 February 1945, 12 February 1945, 2.

${ }^{67}$ Dr. Banks, Director of Health; Dr. Rosalie I. Shukoff, Chief Bacteriologist; major Lydia B. Edwards, medical officer with Split port detachment. Ibidem.

${ }^{68}$ NARA, RG 59, box 5790, 840.50 UNRRA/1-2645, To AGWAR for State Dept. Repeated to Cairo and London, from JUGAID UNRRA 17 from Hall, 26 January 1945.

${ }^{69}$ UNA, s-1312-0000-0018, Letter of Allan Hall to the members of UNRRA Yugoslav Mission departing for their duty, 1 February 1945.

${ }^{70}$ Ibidem.
} 
omy, nutrition, finance, rehabilitation, social services, and departments of transport, justice, agriculture, etc. They operated to the lowest levels of the provincial and district committees. Such a system effectively managed the production and distribution of goods according to the needs of the Partisans and their guidelines. It was estimated that the system throughout the country was supposed to operate uniformly, although to different degrees of success in different parts of the country, due to the evident "Unevenness of the Yugoslav civilization". ${ }^{71}$ At the same time, the report made it clear that the Partisan movement had no noteworthy competition at the end of $1944 .{ }^{72}$ Taking all these aspects into account, UNRRA's intelligence officers believed those committees were the only ones in Yugoslavia capable of distributing UNRRA's supplies. ${ }^{73}$

\section{Preparations for Jurisdiction Transfer from the AML to UNRRA}

Most of the transport and supply delivery was taken over by the military, which was also involved in the reconstruction of ports, road connections, and tending to the population's most basic health needs. In fact, UNRRA was only getting familiar with the terrain and prepared everything necessary for the arrival of a larger number of staff and building a definite hierarchical structure for the post-military period. With less than 50 colleagues in the country, there was nothing else they could do.

Meanwhile, significant structural shifts within the hierarchy of UNRRA took place. On 9 March, the Yugoslav Mission became fully independent, no longer subordinate to UNRRA's Balkan Mission in Cairo but answering directly to the UNRRA HQ in Washington, D.C. Thus, Hall had to reorganize the operation of the Mission in such a way that it could operate independently within Yugoslavia in the post-military period. ${ }^{74}$ That meant the Headquarters needed to push for new negotiations, this time for an independent agreement. The decisive factor in the talks was still the political situation that accompanied the consolidation of power on the one hand, and the ongoing war in the North, namely in Croatia and Slovenia, on the other. Nevertheless, UNRRA managed to align itself with Yugoslavia's requirements in the agreement, deviating from the stipulations that were required from other recipient countries. ${ }^{75}$

The Yugoslavs formally applied for an independent agreement on 17 October 1944, during the aforementioned Washington meeting between Lehman, Bićanić, and Frangeš, where only some of the principle frameworks of the future agreement were discussed. ${ }^{76}$ The very next day, the representatives of

\footnotetext{
${ }^{71}$ UNA, s-1015-0011-0022, UNRRA Yugoslav Mission: Report for period 8 January - 10 February 1945, 12 February 1945, 4.

${ }^{72}$ Ibidem, 5.

${ }^{73}$ Ibidem, 4.

${ }^{74}$ UNA, s-1021-0024-0018, Yugoslavia, vol. I, Office of Chief of Mission, Historical Monograph, 28.

${ }^{75}$ UNA, s-1021-0001-0006, Negotiation of UNRRA Agreements, Yugoslavia, 1.

${ }^{76}$ UNA, s-1015-0011-0018, Note of meeting between Director General Rudolf Bićanić and Mr. Frangeš, 17 October 1944, 1.
} 
both sides met in a somewhat more exhaustive dialogue, where it was agreed that UNRRA would hand over the initial text of the agreement to the Yugoslavs as proposed. At the same time, they also agreed that UNRRA's representative for further negotiations should be Abraham Howard Feller. Representatives of the Bureau of Supply and Bureau of Area also participated in the negotiations on the UNRRA's side. Bićanić, however, remained the leader of the Yugoslav negotiation team. UNRRA initially wanted to close the negotiations in Washington. The negotiators met there seven times from mid-October to midNovember. Various draft agreements were presented, differing in six main points: supply and arrangements, transfer of ownership, consultation, observation, proceeds of sale and privileges, and immunities. ${ }^{77}$

The Yugoslavs demanded that, six months before the delivery of a particular transport, they would be informed about its contents. They made a proviso in their request saying it was impossible to plan any distribution of supplies unless they knew what would be available. UNRRA's representatives had to disappoint them as such a way of planning was impossible. The UNRRA was dependent on adapting to the situation on the global market and the situation in all the countries they supplied. They did find a compromise, which was then applied to agreements with other recipient countries. The first article of the agreement stipulated that at least six months before the desired supply of certain goods, Yugoslavia had to compile a list of needs, together with a list of priorities for at least three months in advance. That way, each country, including Yugoslavia, was given the opportunity to highlight its supply priorities, while the UNRRA had sufficient time to make every effort to meet the needs of the recipient countries. At the same time, the UNRRA undertook to inform the recipient country at least three months before delivery about which supplies would be delivered with individual transports. ${ }^{78}$

The agreement with the AML secured Yugoslavia the right to distribute aid independently, but now, they also wanted the transfer of ownership of the goods immediately after they reached the Yugoslav ports. They believed this was the only way they could make sure the distribution was exclusively in their hands. UNRRA complied yet again, but the issue was still not resolved in Washington. The impediment was the Yugoslav request that an accountant be present during the transfer of ownership to check that the amount of aid delivered coincided with the amount agreed in the delivery program. Yugoslavia also suggested that in the event of a dispute, Yugoslavia and the Yugoslav Mission would turn to arbitration, which the UNRRA rejected. Article 3 of the agreement later stated that both sides would resolve any misunderstandings in the way that would be deemed most appropriate at the time. ${ }^{79}$

Yugoslavia also managed to eliminate the requirement to consult the UNRRA on distribution. All they needed to do was inform them about the

\footnotetext{
${ }^{77}$ UNA, s-1021-0001-0006, Negotiation of UNRRA Agreements, Yugoslavia, 4-5.

${ }^{78}$ Ibidem, 5-6.

${ }^{79}$ Ibidem, 6-7.
} 
method of distribution. ${ }^{80}$ The Yugoslav negotiating team also rejected the word "inspect" in the stipulation that gave the UNRRA the right to observe and review the correctness of the aid distribution. They believed the word was offensive to the Yugoslav Government. The UNRRA agreed to replace the word "inspect" with "examine". ${ }^{1}$ This time around, the Yugoslavs agreed to the UNRRA's request to review distribution anywhere in the country without hesitation, unlike at the Bari negotiations. ${ }^{82}$

The biggest request made by the Yugoslavs during the Washington negotiations concerned the right to retain some of the proceeds from the sale of UNRRA's supplies. UNRRA was adamant that Yugoslavia was not entitled to any percentage. During the subsequent negotiations at the UNRRA European Regional Office (ERO) in London, it was agreed that Yugoslavia could retain some of the revenue but should earmark it exclusively for projects of Yugoslavia's rehabilitation. ${ }^{83}$ The Yugoslav team also found it unacceptable that UNRRA's personnel would be granted diplomatic immunity. They demanded the immunities to be specified, which Feller ultimately agreed to. However, before UNRRA was able to make its proposal, Yugoslavia suggested that two immunities be eliminated, namely the ones related to prosecution and the inviolability of the Yugoslav Mission premises. UNRRA absolutely rejected limiting immunity from prosecution for all its employees, while proposing that the inviolability of premises would apply to the Yugoslav Mission HQ and the main offices in each Republic. The rest of the UNRRA's premises in Yugoslavia were therefore excluded. But in the end, UNRRA had to budge even further, since Article 6 mentioned only immunity for the Yugoslav Mission HQ. ${ }^{84}$

The Yugoslav negotiators, headed by Bićanić, were extremely successful in restricting the freedoms of the UNRRA's operations and its employees, while the stipulations on the duties of the Yugoslav government remained relatively flexible. The UNRRA's rapporteurs interpreted the situation thusly: ${ }^{85}$

The attitude appears to have been that the agreement was like a commercial contract for the delivery of supplies, to which supplies Yugoslavia was entitled in consideration of her sacrifices during the war.

The stipulations were mainly criticized by the ERO representative, who argued that the contract was too rigid and inflexible and that difficulties in interpreting would arise and too many demands would be made. Nevertheless, the basic spirit of the agreement remained after the Washington negotiations were concluded. Since the atmosphere in Yugoslavia was quite tense at the time, UNRRA's representatives asked Bićanić to explain who even gave him the right to negotiate an agreement with UNRRA in the first place. The question was

\footnotetext{
${ }^{80}$ Ibidem, 8.

${ }^{81}$ Ibidem, 8-9.

${ }^{82}$ Ibidem, 9.

${ }^{83}$ Ibidem, 10-11.

${ }^{84}$ Ibidem, 11.

${ }^{85}$ Ibidem, 12.
} 
addressed to Bićanić after Washington received a suggestion from Cairo to move the negotiations to Bari, where representatives of the NKOJ could be involved. Bićanić maintained that he was authorized to negotiate and represent both Tito and the Government-in-Exile, but things remained open-ended. An order thus came from Cairo not to sign any agreements in Washington for the time being, which led to another negotiations deadlock in mid-November of 1944, similar to the one with the AML. UNRRA Director-General Lehman then traveled to London, quickly followed by Bićanić, who refused to make a definite commitment to what had been agreed so far, even though his authority was questioned by UNRRA. ${ }^{86}$ Lehman and Bićanić, however, did not meet in London at all.

Instead, Lehman met with Sava Kosanović, who soon became the ambassador of the Democratic Federative Yugoslavia (DFY) to the United States, and with Tito's personal envoy to London, General Vladimir Velebit. To Lehman's surprise, both Yugoslavs said they did not see any particular problems that would prevent a quick resolution of the pending issues. As a result, they said that the location where the transfer of the supply ownership would be transferred was irrelevant; that the issue of revenue percentage was merely a misunderstanding; and that the observers were not a problem at all as long as they were in limited numbers. They did suggest that the agreement should not be concluded until the "United Yugoslav Government" negotiations were delayed for another two months, ${ }^{88}$ but in the meantime, an agreement between the AML and the Yugoslav Government was signed, while UNRRA sent its first employees to Yugoslavia. In the first half of February of 1945, the ERO reported that all three Yugoslav representatives, namely Bićanić, Kosanović, and Velebit, traveled to Belgrade to present to the authorities a draft agreement for further talks. As early as 15 February, the UNRRA HQ in Washington stipulated that they would send Lehman's deputy Roy Hendrickson to Belgrade, but his visit was approved by Yugoslavia only on 10 March 1945 . That was only three days after the Provisional Government of Democratic Federal Yugoslavia had been formed, with Tito taking over as president and getting all the powers to sign international agreements.

Hendrickson arrived in Belgrade with the good news that UNRRA had also studied whether Yugoslavia was in a position to repay for UNRRA's supplies and concluded that it was not. ${ }^{89}$ Such an outcome was quite agreeable to the Yugoslav Government. As a result, only a couple of amendments were made to the agreement in the relaxed atmosphere of the last meeting. On 24 March $1945,{ }^{90}$ Tito read the agreement again ${ }^{91}$ before it was signed by Hendrickson

\footnotetext{
${ }^{86}$ Ibidem, 13.

87 Ibidem, 14.

88 Ibidem.

${ }^{89}$ Ibidem, 15.

90 G. Woodbridge, UNRRA, vol. II, 143. The document "Saopštenje o sporazumu privremene vlade DFJ i UNRRA-e" cites the date of signing March 23, 1945. More: Branko Petranović,
} 
and the DFY government representative, Nikola Petrović, minister of trade and supply, in his presence. ${ }^{92}$

The Yugoslav Government's press release, stated, inter alia: ${ }^{93}$

The signed agreement is the basis for the heroic peoples of Yugoslavia who have made such great efforts in the struggle for their liberation and for the common goal of the United Nations, and thus have suffered, as they are still suffering now due to the devastation caused by the enemy - to receive aid.

The agreement stipulated that the UNRRA would assume all powers in the country on 15 April 1945, ending the military period and the AML's jurisdiction in Yugoslavia. To this end, the Yugoslav Mission HQ was opened in Belgrade on 4 April, although one division of the top mission staff remained in Bari, while a supply office in Split continued with its operations. ${ }^{94}$ In addition, regional offices were already operating in Cetinje for Montenegro, in Sarajevo for Bosnia-Herzegovina, and in Zagreb for Croatia. In addition to Split, where the HQ for the distribution management and the regional office for Dalmatia were located, and Dubrovnik, a port office was also opened in Šibenik. ${ }^{95}$ At the same time, UNRRA gradually took control of some of the AML's offices: on 7 March 1945, they took over the agriculture branch; on 21 March the health division; and on 25 March the supply bureau. ${ }^{96}$

On 19 May, a month after assuming all powers, a new mission chief, Michail Sergeichic, a Russian, arrived in Belgrade. ${ }^{97}$ The fact that a representative of the Soviet Union took over the management of the mission was quite telling. Later UNRRA documents suggested that the military period and the operation of the AML in Yugoslavia had indelible consequences, particularly the fact that the government, officials and to some extent civilians, associated the UNRRA with the British and American military and not with all $44 \mathrm{UN}$ countries. At the same time, they also identified some of the pressing issues left over by the AMLS that also hindered the attitudes against UNRRA. The most pressing issues were the delays in announcing the quantities of supplies, which were up to five times smaller than agreed, while the port reconstruction was too slow. ${ }^{98}$ At the lower level, UNRRA warned about the attitude of some military

Momčilo Zečević, Jugoslavija 1918-1988. Tematska zbirka dokumenata (Beograd: Izdavačka radna organizacija Rad, 1988), 789.

${ }^{91}$ That is clearly evident in the recording of the agreement signing made by the Bureau of Public Relations. Available at: 1945, Yugoslavia: Tito Signs UNRRA Pact 220707-04 | Footage Farm: https://www.youtube.com/watch?v=WvgXvM6gCSY (Accessed in December 2019)

${ }^{92}$ UNA, s-1021-0001-0006, Negotiation of UNRRA Agreements, Yugoslavia, 16.

${ }_{93}$ B. Petranović, M. Zečević, Jugoslavija 1918-1988, 789.

${ }^{94}$ UNA, s-1021-0024-0018, Yugoslavia, vol. I, Office of Chief of Mission, Historical Monograph, 28.

${ }^{95}$ Ibidem, 35.

${ }^{96}$ Ibidem, 30 .

${ }^{97}$ D. W. [Duane Wilson, op. a.], Success of a Mission: U.N.R.R.A. in Yugoslavia. The World Today, vol. 2, no. 8, London 1946, 377.

${ }^{98}$ UNA, s-1021-0024-0018, Yugoslavia, vol. I, Office of Chief of Mission, Historical Monograph, 30. 
officers who were degrading or overbearing toward the population as if they were "colonial peoples". 99 So, in addition to all its operational tasks, UNRRA had to mend its reputation with the Yugoslav leaders and the general public.

Some issues were resolved quickly. The Yugoslav State Committee for the AML in Split, which initially was not authorized to conclude any operational arrangements with the UNRRA after its takeover of power, was, for example, soon transformed into the Bureau of Special Supplies (The Institute or ZZVN) under the leadership of Marko Nikezić, who answered directly to the Ministry of Commerce and Supply. It was the Institute that, at the operational level, became the chief partner the UNRRA employees, alongside the minister of commerce. Together, they shaped the supply and aid distribution in Yugoslavia until 1 July 1947, when the Yugoslav Mission was finally abolished together with the rest of the European missions. ${ }^{100}$

\section{REFERENCES}

- History of $A F H Q$, Part One, Part Two \& Part Three. Accessible at: https://apps.dtic.mil/dtic/tr/fulltext/u2/a551517.pdf http://www.dtic.mil/dtic/tr/fulltext/u2/a551521.pdf http://www.dtic.mil/dtic/tr/fulltext/u2/a550768.pdf (Accessed in December 2019).

- Ajlec, Kornelija. „Egipatska vlada i rješavanje izbjegličke problematike tijekom Drugoga svjetskog rata”. Časopis za suvremenu povijest, no. 2, (2014), 295-318.

- Ajlec, Kornelija. „Jugoslovanski begunci v Egiptu in njihova politična opredeljenost 1943-1946". Zgodovinski časopis, vol. 67, no. 3-4, (2013), 428448.

- Ajlec, Kornelija. „UNRRA v Jugoslaviji in Sloveniji”, Prispevki za novejšo zgodovino, vol. 53, no. 2, (2013), 79-99.

- Bundy, Amanda Melanie. There Was a Man of UNRRA: Internationalism, Humanitarianism, and the Early Cold War in Europe, 1943-1947. Dissertation. Columbus: Ohio State University, 2017.

- Fenby, Jonathan. Crucible. Thirteen Months that Forged Our World. London: Simon \&Schuster, 2018.

- Himmelreich, Bojan. „Organizacija preskrbe na osvobojenih ozemljih Slovenije in priprave na povojno obdobje (1944-1945)", Prispevki za novejšo zgodovino, vol. 49, no. 2, (2009), 109-124.

- Kovačević, Miloš (ed.). Vazduhoplovstvo u narodnooslobodilačkom ratu Jugoslavije. Zemun: Komanda Ratnog vazduhoplovstva, 1965.

- Kržišnik-Bukić, Vera. „Hrana kao glavni vid UNRRA-ine pomoći Jugoslaviji 1943-1948”. Časopis za suvremenu povijest, vol. 20, no. 3, (1988), 59-76.

\footnotetext{
${ }^{99}$ Ibidem, 31.

${ }^{100}$ K. Ajlec, UNRRA v Jugoslaviji in Sloveniji, 98.
} 
- Lees, Lorraine. Keeping Tito Afloat: the United States, Yugoslavia, and the Cold War. University Park: Pennsylvania State University, 1997.

- Petranović Branko, i Momčilo Zečević. Jugoslavija 1918-1988. Tematska zbirka dokumenata. Beograd: Izdavačka radna organizacija Rad, 1988.

- Petranović, Branko. „Pomoć UNRE Jugoslaviji”. Istorija 20. veka: zbornik radova, vol. 2, (1961), 163-224.

- Plenča, Dušan. „Jugoslavenski zbjeg u Italiji i Egiptu”. U: Istorija radničkog pokreta. Zbornik radova (knjiga 4). Pero Morača (ur.), 335-447. Beograd: Institut za izučavanje radničkog pokreta, 1967.

- Reinisch, Jessica. "Internationalism in Relief. The Birth (and death) of UNRRA". In: Post-war reconstruction in Europe. Mark Mazower, Jessica Reinish and David Feldman (ed.), 258-289. Oxford: Oxford University Press, 2011.

- The Oxford Companion to World War II. Oxford: Columbia University Press, 2005.

- "What was Dollar from the Past Worth Today?", MeasuringWorth, 2019. Accessible at: www.measuringworth.com/dollarvaluetoday/

- Wilson, Duane. "Success of a Mission: U.N.R.R.A. in Yugoslavia". The World Today, vol. 2, no. 8, (1946), 376-383.

- Woodbridge, George. UNRRA. The History of the United Nations Relief and Rehabilitation Administration, vol. I - III. New York: Columbia University Press, 1950. 
KORNELIJA AJLEC, PhD, Assistant Professor

Department of History, Faculty of Arts, University of Ljubljana

Ljubljana, Republic of Slovenia

kornelija.ajlec@ff.uni-lj.si

UNRRA AND ITS ARRIVAL IN YUGOSLAVIA, 1944-1945

\section{Summary}

As Yugoslavia slowly began to shake off the clutches of occupation, it quickly became clear that the war would leave behind enormous devastation. The damage was such that any political organization taking power in the country would have huge difficulties repairing it. The allies anticipated the problems resulting from the fighting and set up the United Nations Relief and Rehabilitation Administration (UNRRA). The Allied plans for reconstruction included Yugoslavia, but it was first necessary to negotiate with the local authorities and make the appropriate agreements that would allow UNRRA to enter the country. The first UNRRA staff was introduced as part of the Allied Military Liaison (AML), a military organization whose task was also to provide aid to the Allied countries. The period when the AML and UNRRA worked together was the socalled Military Period. At the same time, UNRRA negotiated with the National Committee for the Liberation of Yugoslavia (NKOJ) and finally signed an agreement to work independently in the country. This agreement enabled UNRRA to contribute significantly to the reconstruction of Yugoslavia over the period of the next two years.

KEYWORDS: Yugoslavia, UNRRA, Allied Military Liaison, Negotiations, Humanitarian Aid 